\title{
負荷推定とファジー制御による負荷周波数制御
}

\author{
正員上田昭彦 (東海大) 正員 V. Avatchanakorn (東海大) \\ 正員 M. A. Iskandar (東海大) 正員 水 谷 芳 史 (東海大)
}

\section{Load Frequency Control Via Power Demand Estimation and Fuzzy Control} Akihiko Ueda, Member, Marzan Aziz Iskandar, Member, Vichit Avatchanakorn, Member, Yoshibumi Mizutani, Member(Tokai University)

キーワード：負荷周波数制御, 発電電力の増加率制限, 負荷推定, ファジー制御

電力系統の負荷周波数制御(LFC)問題に対して, 著者らは真荷推定とファジー制御による制御手法を提 案し，良好な LFC 特性をあげることを示した(1)。し かしながら、この手法にお扔るファジー制御は，複数 の制御規則とメンバシッブ関数を必要とし，更に系の すべての動作点に対して制御できず，不連続な制御と なり，応答特性が振動的となる。

これらの問題に対して，本報告では，位相平面を利 用してメンバシップ関数を簡略化すると共に連続的な 制御を与えるファジー制御(2) と，負荷推定を用いた 新しい LFC 手法を提案する。そして, 文献 ( 3 )で用 いた各地域において発電電力の增加率制限を考虑した 非再熱・再熱火力発電所を有する2 地域系を，4地域 系に㹡張した図 1 に示す 4 地域〈し形非線形 LFC モ デルに適用しその有効性を検証する。

本手法はまずLFCの目標を満足させるために， 文献（1）で論じた負荷推定に基づく出力設定制御を実 施する。次に，系の最適化を図るために，位相平面を 利用してメンバシップ関数を簡略化し，連続的な制御 が行えるファジー制御を実施する。

すなわち, 地域 $i$ のアジー制御器に対する第一, 第二の入力変数としては, 各々次式に示す自地域の地 域制御䛊差 $e_{i}$ とその変化分 $\Delta e_{i}$ を用いる。

$$
\begin{aligned}
& e_{i}(k)=\beta_{i} \Delta f_{i}(k)+\sum_{j=1}^{b} a_{i j} \Delta P_{\text {teltj }}(k) \cdots \cdots \cdots \cdots(1) \\
& \Delta e_{i}(k)=e_{i}(k)-e_{i}(k-1) \cdots \cdots \cdots \cdots \cdots \cdots \cdots \cdots(2) \\
& \text { ただし, } \beta_{i}=D_{i}+\left(1 / R_{N i}{ }^{*}+1 / R_{R i}{ }^{*}\right), l: \text { : 地域数 }
\end{aligned}
$$

(1) 式と (2) 式を各々次式に示す大きさ $D_{e i}(k)$, 位相

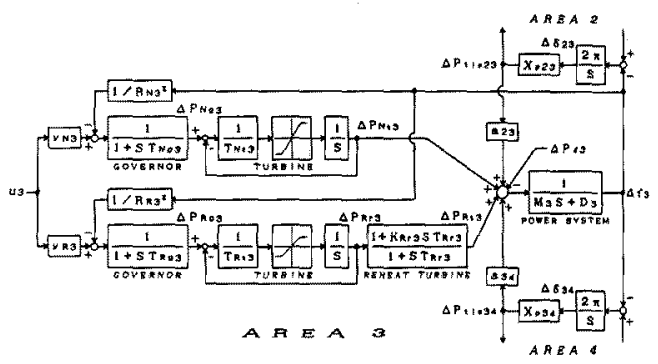

図 14 地域くし形非線形 LFC モデル

Fig. 1. 4-area longitudinal non-linear LFC model.

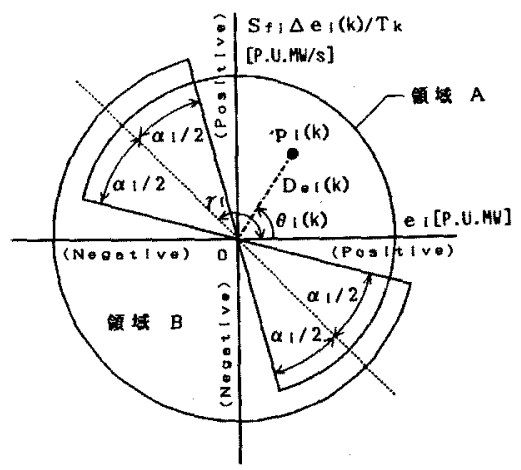

図 2 位相平面

Fig. 2. Phase plane.

角 $\theta_{i}(k)$ に変換し, 図 2 に示す位相平面上に動作点 $p_{i}(k)=D_{e i}(k) / \underline{\theta_{i}(k)}$ をとる。

$$
D_{e i}(k)=\sqrt{e_{i}(k)^{2}+\left\{S_{f i} \Delta e_{i}(k) / T_{k}\right\}^{2}}
$$




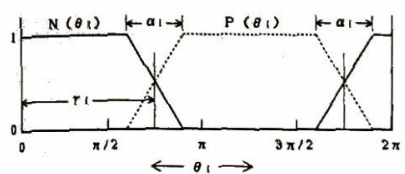

(a) $\theta_{i}(k)$

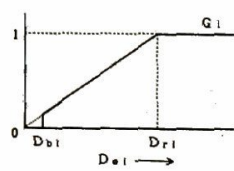

(b) $D_{e i}(k)$
図 3 メンバシップ関数

Fig. 3. Membership function.

$$
\theta_{i}(k)=\cos ^{-1}\left\{\frac{e_{i}(k)}{D_{e i}(k)}\right\}
$$

ただし， $S_{f i}:$ スケーリングファクタ

ここで, 変数 $\theta_{i}(k)$ に対して, $p_{i}(k)$ が領域 $A$ に存 在するときは操作量を負方向に, $p_{i}(k)$ が領域 $B$ に存 在するときは操作量を正方向にとるように制御を実施 する。また，操作量の切換えは，第 2 , 第 4 象限にお けるパラメータ $\gamma_{i}=135^{\circ}, 315^{\circ}$ によって行われる。す なわち, 変数 $\theta_{i}(k)$ に対するメンバシップ関数恃図 3(a)のように構成される。ただし， $\alpha_{i}$ はファジー領 域を示すパラメータである。変数 $D_{e i}(k)$ に対し, (b)図に示すメンバシップ関数を用いて制御ゲイン $G_{i}(k)$ を求める。ただし， $D_{b i}$ は不感帯を意味する。

これらより, ファジー制御操作量 $v_{F i}{ }^{*}(k)$ は, 次式 のように算出される(4)。

$$
v_{F i}^{*}(k)=\frac{N\left\{\theta_{i}(k)\right\}-P\left\{\theta_{i}(k)\right\}}{N\left\{\theta_{i}(k)\right\}+P\left\{\theta_{i}(k)\right\}} \eta_{i} G_{i}(k)
$$

ただし， $\eta_{i}$ :ファジー制御操作量の最大值を

表すパラメータ, $P\left\{\theta_{i}(k)\right\}=1-N\left\{\theta_{i}(k)\right\}$

更に，本手法では，ファジー制御操作量の決定にお いて演算時間遅れを 1 サンプル周期と仮定し， $k$ 時刻 の制御操作量 $u_{F i}(k)$ を次式のように表す。

$$
u_{F i}(k)=v_{F i}^{*}(k-1)
$$

この結果, 制御入力 $u_{i}$ は次式のようになる。

$$
u_{i}(k)=r_{i}(k)+u_{F i}(k)
$$

ただし， $r_{i}$ : 負荷推定による出力設定值

本報告では, 文献 $(5)$ 亿基づき上述のファジー制御 器を設計した。すなわち, 基準となる負荷外乱として は, 朝の立上りなどに見られる大きな負荷変動 $\Delta P_{\text {dimax }}=0.03 \mathrm{pu} \mathrm{MW}$ を用いる。パラメータ $\alpha_{i}$ は, ファジー領域を最大限に利用する意図から $\alpha_{i}=90^{\circ}$ に 設定する。 $D_{r i}$ は各地域で基準となる負荷外乱を与え たとき， $D_{e i}$ の最大値とする。 $\eta_{i}$ は，次式の評価関数 を最小化し，更に全系で協調をとりながら最適化をは 功るうに決定した。

$$
J_{i}=\sum_{j=1}^{l}\left[\int\left\{\left(e_{j}(t) t\right)^{2}+\left(u_{F j}(t) t\right)^{2}\right\} d t\right]
$$

図 4 は, 図1のモデル系統に対して $0.03 \mathrm{puMW}$

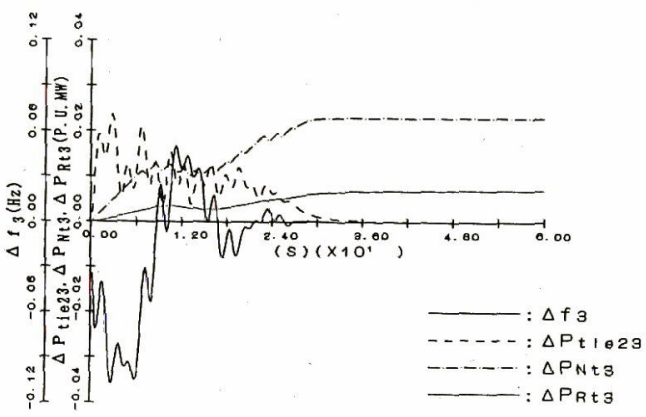

(a) 本手法 $\left(S_{f i}=2.0, D_{b i}=0.005 D_{r i}\right)$

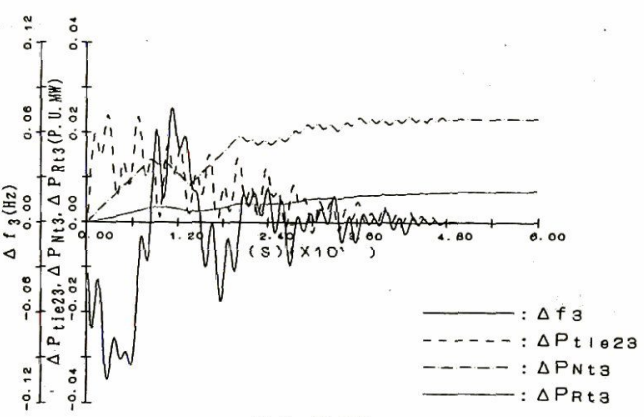

(b) 従来法

図 4 応答比較（サンプル周期 $T_{k}=0.02 \mathrm{~s}$ )

Fig. 4. Response comparison $\left(T_{k}=0.02 \mathrm{~s}\right)$.

のステップ状負荷外乱を地域 3 に与えた場合の応答特 性である。ただし，(a)図は本手法，(b)図は文献 （1）に基づく従来法を適用した場合である。これらよ り, 本手法の特性は速やかに収束し, 振動が抑兑ら れ，良好な応答特性を示している。

(平成 3 年 3 月 27 日受付)

\section{文献}

（1）Avatchanakorn •上田・後藤・水谷：電学論 B, 110, 841(平 $2-10$ )

（2）檜山・鮫島：電気学会電力技術研資，PE-89-133(平元)

(3) 上田・Avatchanakorn·Iskandar 水谷: 電気学会電力技術 研資, PE-90-139(平 2)

（4）菅野：ファジィ制御(昭 63) 日刊工業新聞社

（5）上田・Iskandar -Avatchanakorn - 水谷：平 3 電学会全大, No.1184

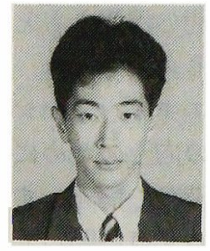

\section{上田昭 彦 (正員)}

昭和 40 年 5 月 1 日生。平成 3 年 3 月東海大学大学院修士課程修了。 同年 4 月(株) 東芝入社, 現在に至 る。

（M. A. Iskandar 以下，写真・略歴省略） 